DOI: https://doi.org/10.47405/mjssh.v5i10.516

\begin{tabular}{|c|c|}
\hline 4 & Malaysian Journal of Social Sciences and Humanities (MJSSH) \\
\hline $\begin{array}{l}\text { Malaysian Journal of } \\
\text { Social sciences and }\end{array}$ & Volume 5, Issue 10, October 2020 \\
\hline (MJ-SSH) & e-ISSN : 2504-8562 \\
\hline & $\begin{array}{l}\text { Journal home page: } \\
\text { www.msocialsciences.com }\end{array}$ \\
\hline
\end{tabular}

\title{
Persepsi Masyarakat Tempatan Terhadap Pengurusan E-sisa oleh Syarikat Swasta di Bandaraya Kota Kinabalu, Sabah
}

\author{
Molia Sebi Dinggai', Mohammad Tahir Mapa1, Fionna George ${ }^{1}$ \\ ${ }^{1}$ Fakulti Kemanusiaan, Seni dan Warisan, Universiti Malaysia Sabah \\ Correspondence: Molia Sebi Dinggai (morrymomo102@gmail.com)
}

\begin{abstract}
Abstrak
Kajian ini bertujuan untuk melihat persepsi masyarakat tempatan terhadap pengurusan e-sisa oleh syarikat swasta di bandaraya Kota Kinabalu, Sabah. Pengurusan e-sisa yang sistematik sepatutnya terintegrasi antara semua pemegang taruh seperti pihak kerajaan, pihak swasta, pihak nongovernmental organization, sektor informal dan juga masyarakat tempatan. Namun di Sabah khususnya di Kota Kinabalu, peranan syarikat swasta merupakan antara pemegang taruh yang kurang jelas penglibatannya dalam pengurusan e-sisa. Oleh itu, objektif utama artikel ini adalah untuk menilai persepsi masyarakat tempatan terhadap pengurusan e-sisa yang dijalankan oleh syarikat swasta di bandaraya Kota Kinabalu, Sabah. Kajian ini menggunakan borang soal selidik sebagai instrumen utama yang telah diedarkan kepada 400 responden yang terdiri daripada isi rumah. Analisis deskriptif seperti nilai purata skor digunakan untuk menganalisis data bagi menjawab objektif kajian. Hasil kajian mendapati bahawa masyarakat tempatan memberikan persepsi yang baik terhadap pengurusan e-sisa yang dijalankan oleh syarikat swasta di bandaraya Kota Kinabalu. Oleh itu, diharapkan kajian ini dapat memperlihatkan persepsi masyarakat tempatan terhadap pengurusan e-sisa yang dijalankan oleh syarikat swasta di bandaraya Kota Kinabalu.
\end{abstract}

Kata kunci: e-sisa, pemegang taruh, syarikat swasta, persepsi

\section{Local Community Perceptions on E-waste Management by Private Companies in Kota Kinabalu, Sabah Abstract}

This study aims to analyze the perception of the local community on the management of e-waste by private companies in the city of Kota Kinabalu, Sabah. Systematic e-waste management should be integrated between all stakeholders such as the government, the private sector, non-governmental organizations, the informal sector and the local community. However, in Sabah, especially in Kota Kinabalu, the role of private companies is one of the stakeholders whose involvement in e-waste management is still unclear. Therefore, the main objective of this article is to analyze the perception of the local community on the management of e-waste conducted by private companies in the Kota Kinabalu, Sabah. This study uses a questionnaire as the main instrument that has been distributed to 400 respondents involving of households. Descriptive analysis such as the min scores is used to analyze the data to answer the objectives of the study. The results of the study found that the local community gave a good perception toward the e-waste management carried out by private companies in Kota Kinabalu, Sabah. Therefore, hope that this study can show the perception of the local community on the management of e-waste conducted by private companies in the city of Kota Kinabalu. 
Keywords: e-waste, stakeholders, private companies, perceptions

\section{Pengenalan}

Sisa elektrik dan elektronik ataupun lebih dikenali sebagai e-sisa bukan satu isu yang baru dalam pengurusan sisa pepejal yang semakin membelengu alam sekitar hari ini. Penyataan "each year, more new devices are created, and more new deviced are thrown out" mengambarkan semakin banyak peranti elektrik dan elektronik dicipta akan lebih banyak peranti yang akan dibuang dikemudian hari (Uddin, 2012) .Hal ini kerana berlaku lambakan terhadap peralatan elektronik khususnya telefon bimbit, komputer, komputer riba, televisyen yang sentiasa berubah-ubah reka bentuk dan sentiasa berlaku inovasi mengikut spesifikasi dan permintaan daripada pengguna. Kehadiran pelbagai jenama dan reka bentuk serta penambahan aplikasi yang lebih canggih menyebabkan tempoh jangka hayat barangan elektronik lebih singkat dan hanya mampu bertahan antara satu sehingga tiga tahun mengikut jenis peralatan elektronik (Fionna, Mohammad Tahir, \& Molia, 2019; Swati, Suneel, 2014). Ini secara langsung akan mengundang kepada pencemaran alam sekitar sekiranya tidak diurus dengan betul.

E-sisa asalnya merupakan peralatan elektrik dan elektronik yang telah rosak ataupun tidak digunakan lagi oleh pengguna dan dibuang untuk dilupuskan (Fionna et al., 2019; Nordbrand, 2009; Widmer, Oswald-Krapf, Sinha-Khetriwal, Schnellmann, \& Böni, 2005). Peralatan e-sisa ini mengandungi bahan seperti besi dan keluli yang digunakan untuk membuat sarung dan bingkai, logam bukan ferus seperti tembaga yang digunakan di dalam wayar, aluminium dan kaca yang digunakan untuk membuat skin dan paparan tingkap komputer, komponen elektronik dan juga bahan lain seperti getah, kayu, seramik dan tektil (Kiddee, Naidu, \& Wong, 2013). Kehadiran logam-logam berharga seperti ini menjadikan peralatan e-sisa masih boleh dikitar semula untuk mendapatkan semula bahan mentah didalam setiap peralatan. Sekaligus ini akan dapat mengurangkan perbelanjaan untuk membeli bahan mentah bagi menghasilkan produk yang baru. Meskipun sesetengah daripada bahan tersebut mengandungi bahan berharga tetapi sebahagiannya pula masih lagi mengandungi bahan yang berbahaya terhadap alam sekitar seperti merkuri, plumbum dan arsenik. Oleh itu, sekiranya tidak diurus dengan betul, bahan toksik ini akan terlepas ke perseran dan berpotensi membahayakan kesihatan manusia dan mencemarkan alam sekitar.

Penyataan "waste is misplaced wealth" merupakan penyataan yang mula dibicarakan dalam pengurusan sisa kerana terdapat sisa seperti kertas, botol, kaca dan aluminium yang boleh dijual kepada syarikat kitar semula dan mampu memberikan imbuhan kepada penjualnya Uddin (2012). Begitu juga yang berlaku kepada e-sisa. Menurut Uddin (2012), kebolehan e-sisa untuk dikitar semula dan mengeluarkan logam berharga daripada e-sisa menjadikan perniagaan mengitar semula e-sisa adalah perniagaan yang menguntungkan. Tetapi, mengeluarkan logam berharga daripada peralatan e-sisa bukanlah satu proses yang mudah dan bersifat mesra alam terutamanya tanpa penggunaan mesin-mesin yang berteknologi tinggi dan mahal. Oleh itu, bagi negara yang sedang membangun seperti Malaysia, sektor informal yang kebiasaannya dikaitkan dengan cara pengurusan yang meminimumkan penggunaan teknologi kerana cara tersebut lebih menjimatkan perbelanjaan pengurusan. Tambahan lagi, kerja hanya dilakukan menggunakan tangan dan beberapa peralatan seperti tukul besi untuk memecahkan peralatan e-sisa.

Kebolehan e-sisa untuk menjadi perniagaan yang menguntungkan menjadikan banyak syarikat swasta mula berminat untuk menjalankan perniagaan membeli semula e-sisa daripada masyarakat tempatan bagi mendapatkan logam berharga daripada peralatan e-sisa yang diperolehi. Tidak dapat dinafikan bahawa kebanyakkan peralatan e-sisa mengandungi pelbagai kandungan berharga yang boleh dikitar semula. Menurut Baldé et al. (2015), terdapat 60 unsur atau elemen boleh didapati dalam peralatan elektronik dan secara teknikalnya sesetengah daripada bahan tersebut boleh didapatkan semula dengan had harga yang disetkan semula dipasaran. Manakala Uddin (2012) menyatakan bahawa sisa merupakan sumber kekayaan yang tidak selamanya dipandang rendah khususnya dalam e-sisa. Hal ini kerana boleh dilihat di dalam kandungan e-sisa yang terdapat besi berharga seperti emas, perak, 
tembaga, platinum, dan pladium, juga bahan berharga yang lain seperti besi, aluminium dan juga plastik yang boleh dikitar semula

Di negara sedang membangun seperti Thailand, Indonesia, Filipina bahkan Malaysia orang awam lebih memilih untuk menghantar e-sisa mereka ke sektor informal yang juga syarikat swasta untuk mendapatkan pulangan (Japan International Cooperation Agency, 2014). Harga belian e-sisa pula ditentukan dengan keadaan fizikal e-sisa, umur e-sisa dan juga jenis peralatan. Meskipun harga jualan bukanlah dalam nilai yang tinggi tetapi sesetengah pekerja dan juga masyarakat tempatan khususnya yang berpendapatan rendah yang terlibat dalam pengutipan dan penjualan e-sisa berpendapat bahawa esisa ini mampu memberi nafkah hidup kepada mereka (Chi, Streicher-Porte, Wang \& Reuter, 2011). Oleh itu, kajian ini diwujudkan untuk memberi fokus kepada persepsi masyarakat tempatan berkaitan dengan pengurusan yang dilakukan oleh syarikat swasta di bandaraya Kota Kinabalu, Sabah. Akhir sekali kajian ini diharap dapat memberi maklumat dan akhir sekali dapat membantu pihak Dewan Bandaraya Kota Kinabalu dalam merangka polisi dan juga undang-undang berkaitan dengan e-sisa yang dijalankan oleh pihak syarikat swasta di Kota Kinabalu.

\section{Sorotan Literatur}

\section{Persepsi Masyarakat Tempatan}

Penglibatan syarikat swasta dalam mengurus e-sisa memang tidak dinafikan lagi terutama dalam penyediaan modal, teknologi dan juga tenaga kerja yang professional dalam mengendalikan proses pelupusan e-sisa. Terdapat dua bentuk pengurusan syarikat swasta yang dikenalpasti dalam pengurusan e-sisa iaitu pengurusan berlesen dan juga pengurusan tanpa lesen. Pengurusan syarikat swasta berlesen dikenali sebagai kontraktor yang diberi lesen oleh JAS untuk menguruskan e-sisa dari awal proses pengumpulan sehingga proses pelupusan e-sisa (Jabatan Alam Sekitar, 2015). Manakala pengurusan syarikat swasta tidak berlesen terdiri daripada pusat-pusat penggumpulan dan juga scavenger yang mengutip e-sisa secara persendirian dan tidak berdokumentasi dan tidak diketahui wujud oleh JAS.

Pengurusan e-sisa yang dijalankan oleh syarikat swasta kelihatan tidak jauh beza dengan pengurusan sektor informal dalam mengendalikan e-sisa. Berdasarkan Wilson, Velis, \& Cheeseman (2006), kegiatan yang berorentasikan buruh kasar, teknologi rendah, dibayar dengan kadaran yang minimum serta masa berkerja yang tidak teratur dan tidak dikawal merupakan ciri-ciri pekerjaan yang dilakukan dalam sektor informal. Ciri-ciri ini juga jelas sekali digunakan oleh Chatterjee \& Kumar (2009) dan Niyati (2014) dalam memperincikan skop kerja pekerja di India dalam kajian mereka, dimana pekerja di India mengendalikan lebih 10000 sehingga 20000 tan e-sisa setiap tahun tetapi dibayar gaji Rs 150/hari atau lebih kurang RM8.58 sehari dalam mata wang Malaysia. Malah, skop kerja mereka merangkumi melakukan aktiviti pemecahan e-sisa tanpa peralatan yang sesuai dan sangat terdedah kepada bahaya.

Berdasarkan Rajah 1 dapat dilihat bagaimana peranan syarikat swasta dalam mengurus e-sisa di Malaysia. Kekurangan sektor formal dalam mengurus e-sisa menyebabkan syarikat-syarikat swasta giat berkembang di Malaysia bagi mengaut keuntungan daripada hasil penjualan e-sisa. Menurut kajian Japan International Cooperation Agency (2014) di Malaysia, proses mengurus e-sisa dimulakan apabila pekerja syarikat akan melakukan pengumpulan e-sisa menggunakan lori dan membuat pengumuman berkenaan dengan tujuan mereka mengumpul e-sisa yang tidak diperlukan lagi menggunakan pembesar suara mengelilingi taman perumahan. Kaedah ini juga turut digunapakai oleh syarikat swasta daripada negara lain seperti di Indonesia dan juga Thailand. Hasil kajian lepas juga turut menyatakan bahawa berlaku pemecahan terhadap peralatan e-sisa yang diterima oleh syarikat swasta untuk mendapatkan logam berharga yang akan dijual semula berdasarkan harga pasaran (Suja, Abdul Rahman, Yusof \& Masdar, 2014). Terdapat juga kajian lepas di Macau mendapati kekurangan sektor formal dalam mengurus e-sisa menjadikan syarikat swasta kecil mula menapak dan mengumpul e-sisa khususnya daripada orang awam (Song, Wang \& Li, 2012). Kajian tersebut turut disokong oleh Liu, Tanaka, dan Matsui (2006) dimana syarikat swasta memainkan peranan aktif dalam penggumpulan e-sisa di China kerana orang awam dilihat menerima baik pendekatan mereka yang membeli peralatan e-sisa yang 
telah rosak dan mereka juga mendapat bayaran dengan menjual peralatan elektrik yang mereka tidak perlukan lagi.

Rajah 1: Aliran e-sisa daripada industri dan isi rumah di Malaysia

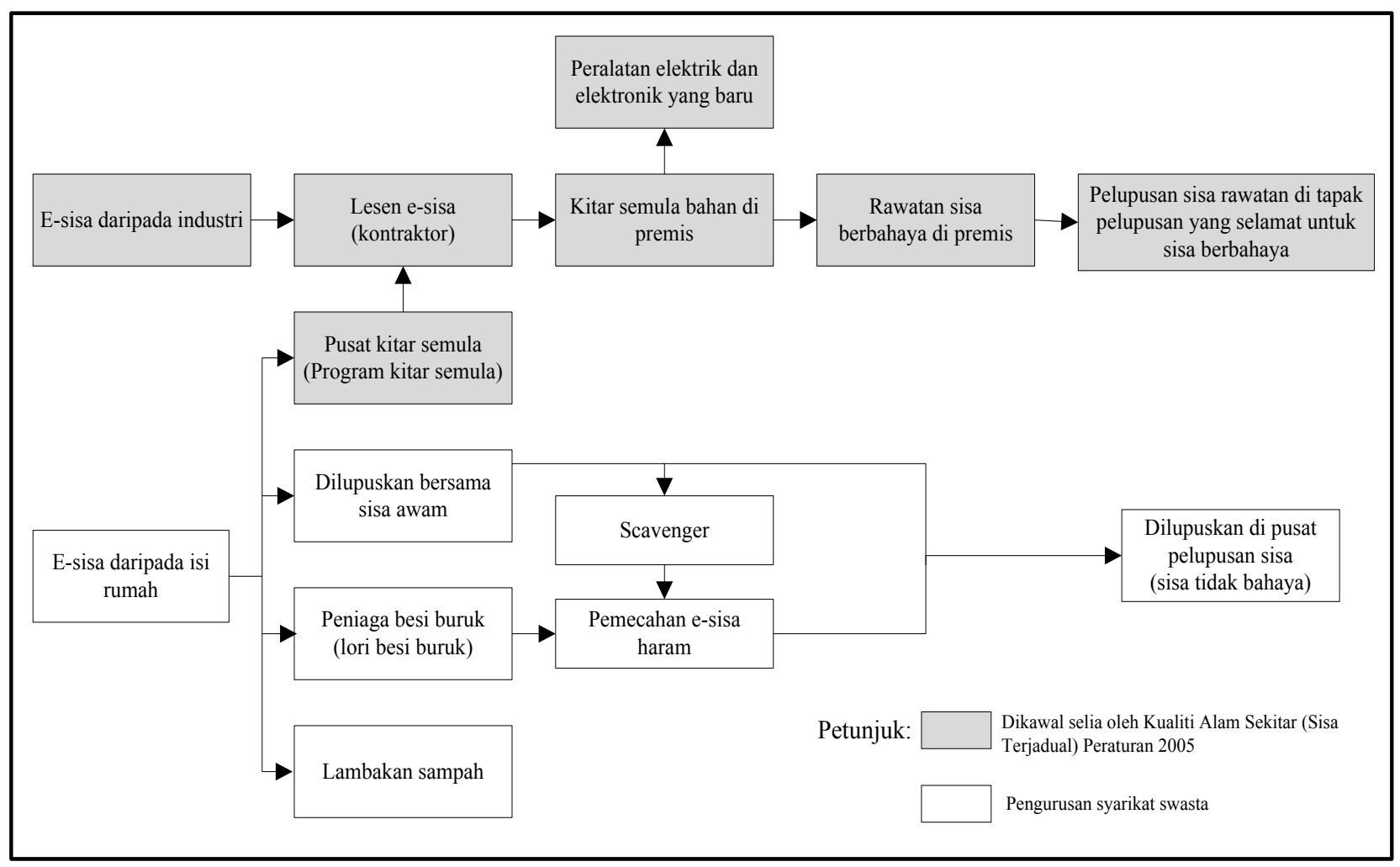

Sumber: Diubahsuai daripada Tengku Adeline (2011)

Seterusnya, penyertaan orang awam dalam pengurusan e-sisa dilihat pada kesanggupan mereka membayar yuran bagi setiap e-sisa yang mereka hasilkan. Pembayaran yuran ini adalah bagi membantu meringankan beban kerajaan dan badan yang mengurus e-sisa dari segi kewangan (Afroz, Masud, Akhtar \& Duasa, 2013). Namun di Malaysia orang awam tidak bersetuju untuk membayar kepada pihak yang mengurus e-sisa mereka. Misalnya, menurut Kalana (2010) dalam kajian beliau responden akan menyuarakan pertanyaan seperti "kenapa saya perlu membayar jika saya boleh menjual e-sisa dan mendapat duit daripada e-sisa tersebut?". Tambahan lagi, ketiadaan satu peraturan khas yang memaksa orang awam membayar bagi e-sisa yang mereka lupuskan menjadikan kerajaan sukar untuk mendekati orang awam supaya turut serta dalam program mengitar semula e-sisa. Kajian tersebut turut disokong oleh kajian yang dilakukan oleh Huisman \& Commission (2014) dimana penduduk di China lebih memilih untuk menjual e-sisa mereka berbanding menghantar ke pusat kitar semula yang formal untuk mendapatkan duit.

Selain itu, terdapat juga kajian di Macau, China dimana orang awam tidak sanggup membayar untuk mengitar e-sisa mereka kerana sebab-sebab tertentu. Pertama, mereka berasa bahawa pada masa lampau pengutipan sisa rumah dan e-sisa adalah percuma dan mereka masih lagi ditakuk pemikiran bahawa pihak kerajaan yang bertanggungjawab dalam pengurusan sisa bukan mereka. Kedua, e-sisa di Macau boleh dijual kepada syarikat swasta kecil yang membeli e-sisa jadi mereka berasa daripada mengeluarkan duit untuk mengurus e-sisa, mereka bahkan mendapat duit daripada menjual e-sisa mereka. Ketiga, kebanyakkan isi rumah di Macau mempunyai pendapatan yang dibawah paras sederhana dan ianya agak menekan mereka apabila mereka perlu membayar untuk e-sisa yang mereka lupuskan. Oleh itu, menjual e-sisa mereka merupakan salah satu cara untuk mereka mendapatkan duit lebih. Keempat, penduduk di Macau masih berpuas hati dengan status quo mereka yang tidak perlu membayar untuk melupuskan e-sisa seperti sebelum ini jadi mereka mahu kekal begitu (Song et al., 2012). Selari dengan kajian yang dijalankan oleh Japan International Cooperation Agency (2014) di Malaysia, penduduk di Malaysia khususnya di Penang dan Selangor juga lebih tercenderung untuk 
menghantar e-sisa mereka kepada syarikat penggumpulan e-sisa yang dijalankan oleh syarikat swasta kerana mereka akan dibayar untuk setiap peralatan yang mereka hantar.

\section{Metod Kajian}

Kota Kinabalu dipilih sebagai kawasan kajian kerana fungsinya sebagai ibu negeri bagi sabah. Tambahan pula, menurut Noor, Marzuki, Mapjabil, \& Eboy (2016) fungsi Kota Kinabalu bukan hanya sebagai pusat pentadbiran sahaja. Malahan menjadi tumpuan bagi pelancongan di Sabah. Pada tahun 2010 penduduk yang menetap di Kota Kinabalu sahaja mencapai jumlah sebanyak 462963 orang daripada 3206742 juta orang jumlah penduduk di Sabah. Sehingga Jabatan Perangkaan Sabah turut mengganggarkan bahawa pertambahan penduduk di kawasan ini peningkat sebanyak 6 peratus setiap tahun dan akan mencapai 500000 orang pada tahun 2015. Tidak mustahil pada tahun 2019 jumlah penduduk yang menetap di Kota Kinabalu akan mencecah sehingga 600000 orang. Oleh kerana kajian ini berfokus kepada pengurusan e-sisa oleh syarikat swasta. Terdapat lima syarikat swasta yang difokuskan dalam kajian ini. Syarikat-syarikat tersebut ialah syarikat Multihope Enterprise Sdn Bhd, SMAPO Sdn Bhd, Berusaha Jaya Trading, GNC Recycle Sdn Bhd, dan Yung Fatt Scrap Metal Sdn Bhd (rujuk Peta 1).

\section{Peta 1: Lokasi kawasan kajian}

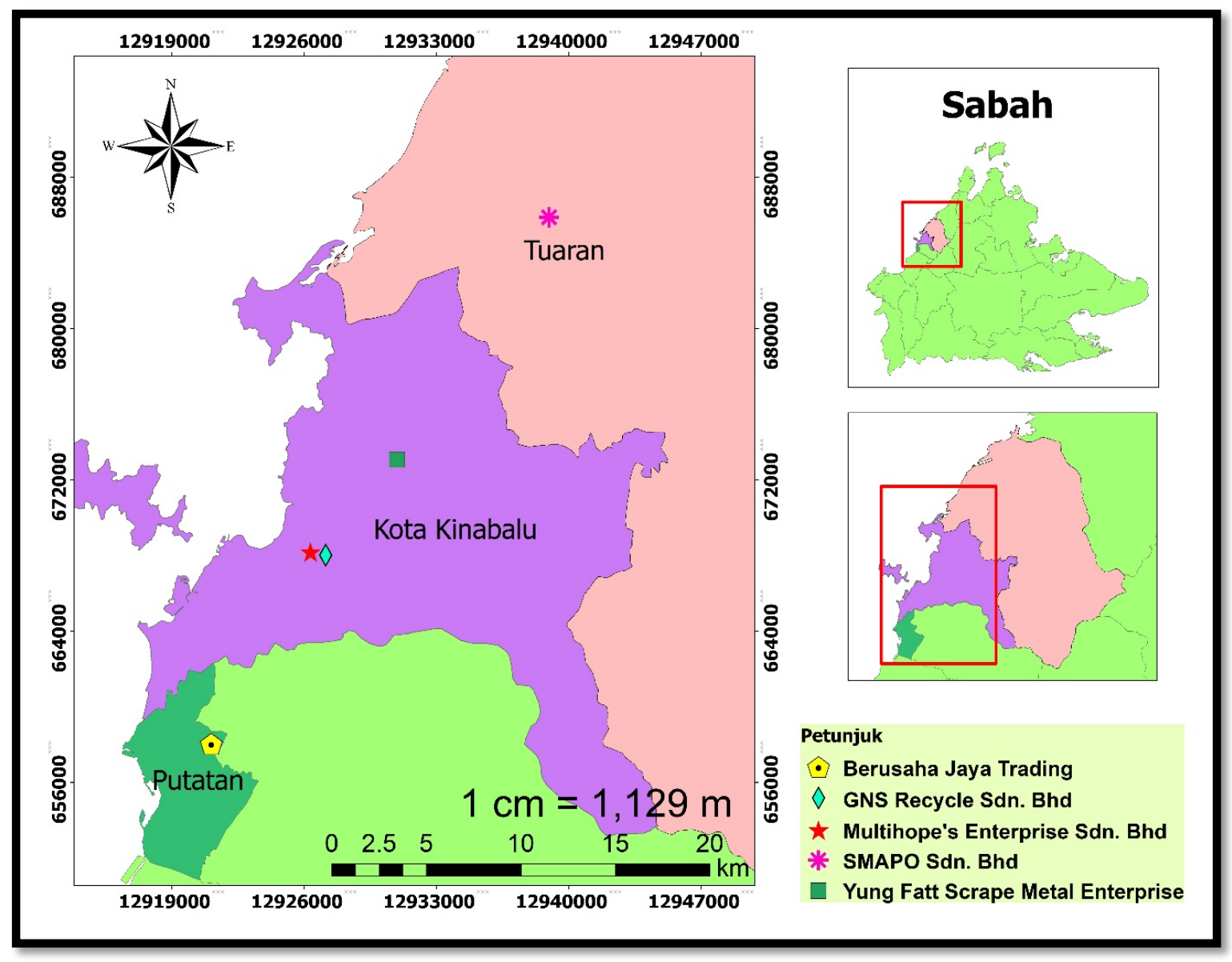

Sumber: Diubahsuai daripada Jabatan Ukur dan Pemetaan Sabah, (2018)

Kajian ini melibatkan interaksi antara syarikat swasta dan juga masyarakat tempatan untuk melihat persepsi masyarakat terhadap pengurusan e-sisa yang dijalankan oleh syarikat swasta. Oleh itu, borang soal selidik digunakan sebagai instrument bagi mendapatkan data. Sampel kajian terdiri daripada 400 orang responden yang dipilih secara rawak di kawasan perumahan yang terdapat di kawasan Telipok, Kota Kinabalu, Inanam dan juga Sepanggar. Set borang soal selidik mempunyai dua bahagian utama iaitu Bahagian A (maklumat responden) dan Bahagian B (persepsi isi rumah terhadap pengurusan sisa 
elektronik oleh pihak swasta). Soalan pada borang soal selidik ini dirujuk daripada kajian "Local Government's waste material management with private sector- A case study in Kota Kinabalu City Sabah, Malaysia" tetapi diubah mengikut kesesuaian kajian. Seterusnya, data yang diperoleh pula dianalisis menggunakan perisian Statistical Package for the Social Sciences (SPSS) menggunakan analisis deskriptif seperti frekuensi dan nilai skor min.

Bagi mengukur persepsi masyarakat tempatan terhadap pengurusan e-sisa yang dijalankan oleh syarikat swasta, skala Likert digunakan dengan mengambil kira lima kategori utama iaitu 1 (sangat tidak setuju), 2 (tidak setuju), 3 (tidak pasti), 4 (setuju) dan 5 (sangat setuju). Seterusnya, nilai skor dibahagikan kepada tiga kategori iaitu rendah, sederhana, dan tinggi. Tiga pengkelasan nilai skor ini turut digunakan oleh Noorazuan (2018) dalam kajian beliau dengan tiga paras nilai skor iaitu rendah (bagi nilai skor 1.00 sehingga 2.33), sederhana (bagi nilai skor 2.34 sehingga 3.67) dan tinggi (bagi nilai skor 3.68 sehingga 5.00).

\section{Hasil Kajian dan Perbincangan}

Berdasarkan Jadual 1, hasil daripada 400 orang responden yang menjawab borang soal selidik sebanyak 53.3 peratus responden dengan jumlah 213 orang adalah lelaki. Manakala, sebanyak 46.8 peratus dengan jumlah sebanyak 187 orang responden adalah perempuan. Bagi kategori umur pula, lingkungan umur paling tinggi ialah diantara umur 20 sehingga 29 tahun dengan peratusan sebanyak 32.0 peratus. Seterusnya, responden yang berumur diantara 30 sehingga 39 mencatatkan peratusan kedua tinggi dengan peratusan 29.0 peratus. Terdapat juga responden yang telah lanjut usia sebagai responden kajian ini yang berumur dalam lingkungan 60 tahun dan keatas dengan peratusan sebanyak 7 peratus. Kategori umur 18 tahun dan kebawah merupakan lingkungan umur paling sedikit responden dengan peratusan 0.3 peratus. Hal ini kerana, rata-rata responden yang dipilih adalah ketua isi rumah dan responden yang dibawah umur 18 tahun dipilih apabila ketiadaan ibu bapa ataupun penjaga di rumah ketika soal selidik diedar atas urusan bekerja atau tiada di rumah ketika itu.

Jadual 1: Latar belakang responden

\begin{tabular}{|c|c|c|c|c|c|}
\hline \multirow[t]{2}{*}{ Bil. } & \multirow[t]{2}{*}{ Karakter } & \multirow{2}{*}{$\begin{array}{l}\text { Jumlah } \\
\text { (n) }\end{array}$} & \multicolumn{3}{|l|}{ Statistik } \\
\hline & & & Karakter & Frekuensi (f) & Peratus $(\%)$ \\
\hline \multirow[t]{6}{*}{1.} & Umur & 400 & 18 tahun dan ke bawah & 1 & 0.3 \\
\hline & & & $20-29$ tahun & 129 & 32.0 \\
\hline & & & $30-39$ tahun & 116 & 29.0 \\
\hline & & & $40-49$ tahun & 64 & 16.0 \\
\hline & & & $50-59$ tahun & 62 & 15.7 \\
\hline & & & 60 tahun dan ke atas & 28 & 7.0 \\
\hline \multirow{2}{*}{2.} & Jantina & 400 & Lelaki & 213 & 53.3 \\
\hline & & & Perempuan & 187 & 46.8 \\
\hline \multirow{3}{*}{3.} & Taraf & 400 & Bujang & 89 & 22.3 \\
\hline & Perkahwinan & & Berkahwin & 310 & 77.5 \\
\hline & & & Duda & 1 & 3 \\
\hline \multirow[t]{2}{*}{4.} & Tahap & 400 & Pendidikan Rendah & 167 & 41.8 \\
\hline & Pendidikan & & Pendidikan Tinggi & 223 & 58.2 \\
\hline \multirow[t]{5}{*}{5.} & Pekerjaan & 400 & Kerajaan & 116 & 29.0 \\
\hline & & & Bekerja Sendiri & 106 & 26.5 \\
\hline & & & Swasta (Profesional) & 27 & 6.8 \\
\hline & & & Swasta & 61 & 15.3 \\
\hline & & & Lain-lain & 90 & 22.5 \\
\hline \multirow[t]{2}{*}{6.} & $\begin{array}{l}\text { Pendapatan } \\
\text { Bulanan }\end{array}$ & 400 & $\begin{array}{l}\text { Tinggi (RM3501- } \\
\text { RM4500) }\end{array}$ & 135 & 33.8 \\
\hline & & & Rendah (RM0-RM3500) & 265 & 66.2 \\
\hline
\end{tabular}


Majoriti responden yang terpilih adalah telah berkahwin, daripada 400 orang responden 77.5 peratus responden berstatus berkahwin, manakala 22.3 peratus lagi pula masih bujang. Bagi responden yang berstatus duda pula adalah sebanyak 3 peratus. Seterusnya, tahap pendidikan dibahagikan kepada dua kategori iaitu pendidikan tinggi dan juga pendidikan rendah. Pendidikan tinggi yang dimaksudkan disini adalah Sijil Tinggi Pelajaran Malaysia (STPM), diploma dan ijazah. Pendidikan rendah pula terdiri daripada Ujian Penilaian Sekolah Rendah (UPSR), Penilaian Menengah Rendah (PMR) dan Sijil Pelajaran Malaysia (SPM). Sebanyak 58.2 peratus responden mempunyai pendidikan tinggi dan selebihnya 41.8 peratus responden pula hanya memiliki pendidikan rendah.

Bagi sektor pekerjaan pula, sebanyak 29.0 peratus responden bekerja dalam sektor kerajaan. Manakala sebanyak 26.5 peratus responden bekerja sendiri dan 15.3 peratus responden bekerja di sektor swasta. Sebanyak 6.8 peratus responden pula bekerja dalam sektor swasta yang diklasifikasikan sebagai bidang profesional seperti jurutera, doktor, guru, dan jururawat. Namun begitu, sebanyak 22.5 peratus responden pula terdiri daripada suri rumah, pelajar, pencen, petani dan juga tidak mempunyai sebarang pekerjaan. Bagi pendapatan bulanan pula, responden yang berpendapatan tinggi adalah sebanyak 33 peratus dan responden yang berpendapatan rendah pula adalah 66.2 peratus.

Jadual 2: Persepsi Masyarakat Tempatan Terhadap Pengurusan E-sisa oleh Syarikat Swasta

\begin{tabular}{|c|c|c|c|}
\hline Bil. & Penyataan & Purata Skor & Paras \\
\hline 1. & $\begin{array}{l}\text { Syarikat swasta juga sepatutnya } \\
\text { mengadakan kempen berkaitan dengan sisa } \\
\text { elektronik untuk menarik campur tangan } \\
\text { daripada orang awam. }\end{array}$ & 4.60 & Tinggi \\
\hline 2. & $\begin{array}{l}\text { Saya setuju sekiranya terdapat satu tempat } \\
\text { khas pengumpulan sisa elektronik di tempat } \\
\text { kediaman saya. }\end{array}$ & 4.61 & Tinggi \\
\hline 3. & $\begin{array}{l}\text { Saya berpendapat pihak swasta juga } \\
\text { memainkan peranan penting dalam } \\
\text { pengurusan sisa elektronik di kawasan } \\
\text { perumahan. }\end{array}$ & 4.52 & Tinggi \\
\hline 4. & $\begin{array}{l}\text { Saya akan menghantar sisa elektronik saya } \\
\text { ke tempat pengumpulan sisa elektronik } \\
\text { syarikat swasta(besi buruk) sekiranya tidak } \\
\text { diperlukan. }\end{array}$ & 4.20 & Tinggi \\
\hline 5. & $\begin{array}{l}\text { Saya mahu supaya bayaran diberikan jika } \\
\text { menghantar ke pusat pengumpulan syarikat } \\
\text { swasta. }\end{array}$ & 3.83 & Tinggi \\
\hline 6. & $\begin{array}{l}\text { Saya akan hantar barangan elektrik yang } \\
\text { tidak berfungsi jika saya dibayar. }\end{array}$ & 3.92 & Tinggi \\
\hline 7. & $\begin{array}{l}\text { Saya setuju untuk bayar sekiranya ada } \\
\text { syarikat swasta yang datang ke rumah saya } \\
\text { untuk mengumpul sisa elektronik. }\end{array}$ & 3.55 & Sederhana \\
\hline \multirow[t]{2}{*}{8.} & $\begin{array}{l}\text { Saya tidak akan menghantar barangan } \\
\text { elektrik yang rosak ke syarikat swasta } \\
\text { sekiranya tidak dibayar. }\end{array}$ & 3.20 & Sederhana \\
\hline & Purata: & 4.05 & Tinggi \\
\hline
\end{tabular}

Berdasarkan Jadual 2, item soalan "Syarikat swasta juga sepatutnya mengadakan kempen berkaitan dengan sisa elektronik untuk menarik campur tangan orang awam", mempunyai nilai min tertinggi iaitu 4.60 dan berada pada paras tinggi. Melalui nilai tersebut dapat melihat bahawa orang awam sedar bahawa kempen merupakan salah satu alternatif yang terbaik untuk menarik minat dan juga untuk memberi pengetahuan kepada orang awam. Malahan langkah pengurusan e-sisa yang sistematik juga boleh disampaikan terus kepada orang awam agar e-sisa tidak terus dibuang ke tapak pelupusan tetapi 
akan dikitar semula menjadi produk baru ataupun produk secondhand. Hasil kajian ini juga selaras dengan kajian yang dilakukan oleh Tarawneh \& Saidan (2013), yang mana program mempromosikan aktiviti kitar semula boleh membantu menarik minat orang awam sekaligus dapat mengubah tingkah laku isi rumah terhadap pengurusan e-sisa.

Item berkenaan "Saya setuju sekiranya terdapat satu tempat khas pengumpulan sisa elektronik di tempat saya" mempunyai nilai min kedua tertinggi iaitu 4.61 dan berada pada paras tinggi. Majoriti responden bersetuju sekiranya satu tempat khas diwujudkan di kawasan perumahan mereka kerana mereka beranggapan bahawa alternatif tersebut lebih memudahkan dan mereka tidak perlu menghantar jauh peralatan e-sisa yang tidak diperlukan lagi. Melalui kewujudan tempat khas pengumpulan e-sisa ini juga sekaligus dapat menggelakkan peralatan e-sisa terus dibuang ke tong sampah komersial dan berakhir di tapak pelupusan sisa. Misalnya, merujuk akhbar Utusan Borneo Online (2014), Datuk Bandar Dewan Bandaraya Kuching Utara (DBKU), Datuk Abdul Wahap Abang Julai menyatakan bahawa memandangkan DBKU belum ada kemudahan untuk melupus e-sisa maka satu langkah menyediakan tong khas akan disediakan supaya masyarakat dapat menghantar e-sisa mereka dan akan dilupus difasiliti yang sepatutnya. Menurut Tengku Adeline (2011) dalam kajian beliau di Malaysia kewujudan satu lokasi khas untuk menghantar e-sisa di kawasan perumahan adalah perlu kerana norma masyarakat di Malaysia pada masa kini yang lebih memilih untuk menghantar e-sisa terus ke tong sampah berbanding menghantar e-sisa mereka jauh daripada kawasan perumahan kerana mereka mengganggap perkara tersebut membuang masa dan tenaga mereka.

Bagi item "Saya berpendapat pihak swasta juga memainkan peranan penting dalam pengurusan sisa elektronik di kawasan perumahan", mempunyai purata skor yang ketiga tertinggi iaitu 4.52 dan berada di paras tinggi. Hasil kajian ini dianggap sebagai sangat signifikan kerana hala tuju kajian ini yang sangat jelas iaitu melihat perspektif masyarakat dalam pengurusan e-sisa yang dijalankan oleh pihak swasta. Oleh itu, melalui nilai purata skor tersebut dapat disimpulkan bahawa responden majoritinya sedar bahawa dalam mewujudkan pengurusan e-sisa yang mampan, kerjasama daripada semua pihak termasuklah pihak swasta juga adalah perlu. Kajian ini disokong oleh Baldé et al. (2017) yang menyatakan bahawa peranan pihak swasta dilihat apabila mereka mampu menyumbang dalam dana dan teknologi dalam mengurus e-sisa kerana pengurusan e-sisa yang sistematik tidak hanya bergantung kepada peranan pihak kerajaan. Kenyataan ini disokong oleh Tengku Adeline (2011) dalam kajian di Semenanjung Malaysia yang mana kehadiran syarikat swasta sedikit sebanyak membantu pihak kerajaan dalam melupuskan e-sisa. Perkara ini menjadikan penduduk khususnya di Penang dan Selangor amat menerima baik pengurusan syarikat swasta kerana pendekatan mereka yang menawarkan bayaran terhadap setiap peralatan e-sisa yang dihantar oleh penduduk tempatan.

Seterusnya, item berkenaan "Saya akan menghantar sisa elektronik saya ke tempat pengumpulan sisa elektronik syarikat swasta sekiranya tidak diperlukan", menunjukkan nilai purata skor bagi item berkenaan adalah 4.20 dan berada di paras tinggi. Hasil ini membuktikan bahawa peralatan e-sisa yang tidak diperlukan oleh responden tidak terus dibuang ke tapak pelupusan sisa awam tetapi dijual semula oleh responden kepada syarikat swasta yang menguruskan e-sisa. Menurut Japan International Cooperation Agency (2014) menghantar barangan e-sisa kepada syarikat swasta merupakan satu kaedah yang baik kerana e-sisa tidak terus berakhir di pusat pelupusan sisa. Namun begitu, Japan International Cooperation Agency (2014), tidak menafikan bahawa terdapat juga kesan buruk apabila masyarakat lebih memilih untuk menghantar e-sisa kepada syarikat swasta terutamanya yang tidak mempunyai pantauan daripada pihak kerajaan kerana berkemungkinan e-sisa tersebut akan diurus secara haram dan keadaan ini amat membahayakan alam sekitar.

Soalan item "Saya akan hantar barangan elektrik yang tidak berfungsi jika saya dibayar", pula mempunyai nilai min 3.92 dan berada pada paras tinggi. Melalui maklum balas daripada responden, dapat menyedari bahawa orang awam menunjukkan minat yang tinggi terhadap pendekatan belisemula peralatan e-sisa oleh syarikat swasta kerana melalui pendekatan ini orang awam mendapat pulangan semula daripada setiap peralatan yang mereka hantar.

Item "Saya mahu supaya bayaran diberikan jika menghantar ke pusat pengumpulan syarikat swasta", mempunyai nilai min 3.83 turut berada pada paras tinggi. Soalan ini lebih menyentuh secara spesifik 
berkaitan pandangan orang awam terhadap pendekatan beli-semula barangan e-sisa oleh syarikat swasta daripada mereka. Berdasarkan respon yang diterima dalam lihat bahawa lebih separuh daripada responden memberikan respon positif bahawa mereka mahu pulangan diberikan sekiranya mereka menghantar e-sisa ke premis syarikat swasta yang melakukan pengumpulan e-sisa.

Soalan item "Saya tidak akan menghantar barangan elektrik yang rosak ke syarikat swasta sekiranya tidak dibayar", mempunyai nilai min 3.20 iaitu berada di tahap sederhana. Melalui respon daripada orang awam yang berada di tahap sederhana dapat menyimpulkan bahawa orang awam lebih berminat terhadap ganjaran yang diterima bila menghantar e-sisa mereka kepada syarikat swasta. Berdasarkan kajian Ibrahim, Adeline, Tengku \& Harun (2016) di Malaysia, rata-rata responden di beberapa kawasan khususnya di Penang dan Selangor lebih memilih untuk menghantar e-sisa mereka kepada pengutip besi buruk atau syarikat kecil kitar semula yang mengumpul e-sisa kerana tawaran harga yang diberikan oleh tempat tersebut. Kajian ini turut disokong oleh Liu et al. (2006) dalam satu kajian di China yang mana penduduk di Guangdong Province lebih memilih untuk menghantar e-sisa mereka ke syarikat pengumpulan e-sisa yang menawarkan bayaran terhadap e-sisa yang mereka hantar.

Seterusnya, bagi item yang terakhir iaitu "Saya setuju untuk bayar sekiranya ada syarikat swasta yang datang ke rumah saya untuk mengumpul sisa elektronik" mempunyai nilai purata skor 3.55 dan berada pada tahap sederhana. Ini membuktikan bahawa mereka masih mempunyai kesedaran untuk mengurus e-sisa mereka meskipun mereka perlu membayar untuk kos pengurusan. Hasil ini selaras dengan kajian yang dilakukan oleh Tarawneh \& Saidan (2013) di Jordan yang mana isi rumah di Jordan mempunyai tahap kesedaran yang tinggi terhadap persetujuan untuk membayar bagi mengurus e-sisa mereka. Hasil kajian juga turut mendapati isi rumah yang mempunyai pendapatan yang tinggi lebih tercenderung untuk bersetuju membayar bagi menguruskan e-sisa berbanding isi rumah yang berpendapatan rendah.

Secara keseluruhannya, meskipun empat daripada lapan item soalan melebihi purata nilai skor 4.00 dan berada pada tahap tinggi tetapi purata nilai skor bagi lapan item masih lagi berada ditahap tinggi iaitu 4.05. Hal ini menunjukkan masyarakat tempatan memberi pandangan yang baik terhadap pendekatan syarikat swasta dalam melakukan pengumpulan sisa di kawasan mereka.

\section{Kesimpulan}

Artikel ini telah memperlihatkan persepsi masyarakat tempatan terhadap pengurusan e-sisa yang dijalankan oleh syarikat swasta di bandaraya Kota Kinabalu. Hasil kajian mendapati penduduk tempatan menerima baik pendekatan beli semula peralatan elektrik yang dijalankan oleh syarikat swasta. Melalui pendekatan ini penduduk tempatan mendapat sedikit pulangan semula terhadap barangan elektrik yang mereka jual. Malahan penduduk tempatan juga masih beranggapan bahawa peralatan e-sisa mereka masih bernilai walaupun telah rosak. Namun begitu, penduduk tempatan tidak sedar bahawa pengurusan e-sisa yang dijalankan oleh syarikat swasta ini bukan lah pengurusan yang formal dan mampan. Hal ini sekaligus akan mendatangkan kesan negatif terutamanya terhadap alam sekitar sekiranya penduduk tempatan masih tidak mengetahui bahawa menjual peralatan e-sisa mereka kepada syarikat swasta bukanlah satu tindakan yang betul kerana tidak tahu apa yang akan berlaku kepada peralatan e-sisa tersebut dikemudian hari. Sebaliknya, sekiranya peralatan e-sisa tersebut dihantar kepada saluran yang betul sudah tentu e-sisa tersebut akan dikitar semula ataupun akan dilupuskan ke saluran yang betul dan tidak memberi kesan negatif kepada alam sekitar.

\section{Rujukan}

Afroz, R., Masud, M. M., Akhtar, R., \& Duasa, J. B. (2013). Survey and analysis of public knowledge, awareness and willingness to pay in Kuala Lumpur, Malaysia - a case study on household WEEE management. Journal of Cleaner Production, 52, 185-193. https://doi.org/10.1016/J.JCLEPRO.2013.02.004

Baldé, C. P., Forti, V., Gray, V., Kuehr, R., Stegmann, P. (2017). The Global E-waste Monitor 2017 Executive Summary. 
Baldé, C.P. Wang, F., Kuehr, R., Huisman, J. (2015). The global e-waste monitor - 2014.

Chatterjee, S., \& Kumar, K. (2009). Effective electronic waste management and recycling process involving formal and non-formal sectors. International Journal of Physical Sciences, 4(13), 893905. Retrieved from http://www.academicjournals.org/ijps

Chi, X., Streicher-Porte, M., Wang, M. Y. L., \& Reuter, M. A. (2011). Informal electronic waste recycling: A sector review with special focus on China. Waste Management, 31(4), 731-742. https://doi.org/10.1016/j.wasman.2010.11.006

George, F., Mapa, M. T., \& Dinggai, M. S. A. (2019). Preliminary Study on Waste Electrical and Electronic Equipment (WEEE) Management by Households in the Kota Kinabalu City. IOP Conference Series: Earth and Environmental Science, 286(1). https://doi.org/10.1088/1755$1315 / 286 / 1 / 012023$

Huisman, J., \& Commission, E. (2014). The QWERTY / EE Concept Quantifying Recyclability and, (June 2003).

Ibrahim, N. F., Adeline, T., Tengku, A., \& Harun, R. (2016). Pengurusan sisa pepejal di Pulau Pangkor: Isu dan cabaran Solid waste management in Pulau Pangkor: Issues and challenges, 14(14), 50-63.

Jabatan Alam Sekitar, H. G. (2015). Electronic Scheduled Waste Information Systems ( eSWIS ) Accessing to e-SWIS Fill in existing, (25).

Jabatan Ukur dan Pemetaan Sabah, J. U. dan P. S. (2018). No Title. Retrieved from http://www.psupsabah.gov.my/index.php/bm/direktori-agensi/152-jabatan-ukur-dan-pemetaanmalaysia

Japan International Cooperation Agency, (JICA) EX Research Institute lLtd. (2014). Asia Region Data Collection Survey on E-waste Management in Malaysia and Surrounding Countries Final Report Target Countries of the Field Survey in the Study, (July).

Kalana, J. A. (2010). Electrical and Electronic Waste Management Practice by households in Shah Alam , Selangor, Malaysia. International Journal of Environmental Sciences, 1(2), 132-144. https://doi.org/10.6088/ijes.00102010003

Kiddee, P., Naidu, R., \& Wong, M. H. (2013). Electronic waste management approaches: An overview. Waste Management, 33(5), 1237-1250. https://doi.org/10.1016/j.wasman.2013.01.006

Liu, X., Tanaka, M., \& Matsui, Y. (2006). Electrical and electronic waste management in China: Progress and the barriers to overcome. Waste Management and Research, 24(1), 92-101. https://doi.org/10.1177/0734242X06062499

Niyati, M. (2014). Role of Informal Sector in E-waste Recycling, 23, 279-286.

Noor, H. M., Marzuki, M., Mapjabil, J., \& Eboy, O. V. (2016). Keberkesanan perkhidmatan bas mini di Kota Kinabalu. Malaysia Journal of Society and Space, 12(12), 50-62.

Noorazuan Md Hashim, S. M. (2018). Tanggapan , kesedaran dan motivasi masyarakat terhadap penggunaan air hujan sebagai bekalan alternatif bandar Social perception, awareness and motivation of rainwater utilization as an alternative supply in urban area, 3(3), 37-52.

Nordbrand, S. (2009). Out of Control: E-waste trade flows from the EU to developing countries. SwedWatch, Stockholm, 1-46. Retrieved from http://www.medvetenkonsumtion.org/content/images/uploaded/list_4734/130008_1596326399.

Online, U. B. (2014, April 9). Sarawak perlu wujud model pengumpulan, kitar semula sisa elektronik. Retrieved from https://www.google.com/amp/s/amp.utusanborneo.com.my/2014/04/09/sarawakperlu-wujud-model-pengumpulan-kitar-semula-sisa-elektronik

Song, Q., Wang, Z., \& Li, J. (2012). Residents' behaviors, attitudes, and willingness to pay for recycling e-waste in Macau. Journal of Environmental Management, 106, 8-16. https://doi.org/10.1016/j.jenvman.2012.03.036

Suja, F., Abdul Rahman, R., Yusof, A., \& Masdar, M. S. (2014). e-Waste Management Scenarios in Malaysia. Journal of Waste Management, 2014(September), 1-7. https://doi.org/10.1155/2014/609169

Swati Kwatra, Suneel Pandey, S. S. (2014). Understanding public knowledge and awareness on ewaste in an urban setting in India: A case study for Delhi. Management of Environmental Quality: An International Journal, 25(6), 752-765.

Tarawneh, A., \& Saidan, M. (2013). Households Awareness , Behaviors, and Willingness to Participate in E-waste Management in Jordan. International Journal of Ecosystem, 3(5), 124-131. https://doi.org/10.5923/j.ije.20130305.04 


$$
\text { DOI: https://doi.org/10.47405/mjssh.v5i10.516 }
$$

Tengku Adeline Adura Tengku Hamzah. (2011). Making Sense of Environmental Governance: A Study of E-waste in Malaysia. PHD Thesis, 1-323. https://doi.org/10.1016/j.jfo.2010.06.004

Uddin, M. D. J. (2012). Journal And Confrence Paper On ( Enviornment ) E - Waste Management, $2(1), 25-45$.

Widmer, R., Oswald-Krapf, H., Sinha-Khetriwal, D., Schnellmann, M., \& Böni, H. (2005). Global perspectives on e-waste. Environmental Impact Assessment Review. https://doi.org/10.1016/j.eiar.2005.04.001

Wilson, D. C., Velis, C., \& Cheeseman, C. (2006). Role of informal sector recycling in waste management in developing countries. Habitat International, 30(4), 797-808. https://doi.org/10.1016/j.habitatint.2005.09.005 